\title{
Role and relevance of mast cells in fungal infections
}

\section{R. Saluja, M. Metz and Marcus Maurer*}

Department of Dermatology and Allergy, Charite - Universitätsmedizin Berlin, Berlin, Germany

\section{Edited by:}

Toshiaki Kawakami, La Jolla Institute for Allergy and Immunology, USA

Reviewed by:

Elena Voronov, Ben Gurion University of the Negev, Israel

Masato Kubo, Tokyo University of

Science, Japan

*Correspondence:

Marcus Maurer, Department of

Dermatology and Allergy,

Charité - Universitätsmedizin Berlin

Charitéplatz 1, 10117 Berlin, Germany.

e-mail:marcus.maurer@charite.de
In addition to their detrimental role in allergic diseases, mast cells (MCs) are well known to be important cells of the innate immune system. In the last decade, they have been shown to contribute significantly to optimal host defense against numerous pathogens including parasites, bacteria, and viruses. The contribution of MCs to the immune responses in fungal infections, however, is largely unknown. In this review, we first discuss key features of mast cell responses to pathogens in general and then summarize the current knowledge on the function of MCs in the defense against fungal pathogens. We especially focus on the potential and proven mechanisms by which MCs can detect fungal infections and on possible $\mathrm{MC}$ effector mechanisms in protecting from fungal infections.

Keywords: mast cell, fungal infection, toll-like receptors, C-type lectin-like receptors, pro-inflammatory mediators

\section{INTRODUCTION: MAST CELLS AND INNATE IMMUNITY}

Mast cells (MCs) are important effector cells in protective immune responses against pathogens (Marshall, 2004; Galli et al., 2005). They are long-lived cells (surviving, in some cases, for years) with the capacity to respond repeatedly to the same stimulus. They reside in and migrate to tissues that are commonly exposed to the external environment, such as the skin, airways, and intestine, where they can initiate and enhance early responses to environmental threats including pathogens. MCs are preferentially located in the vicinity of blood vessels, nerves, and lymphatic vessels, can regulate vascular permeability and instigate effector cell recruitment by releasing preformed as well as de novo synthesized mediators (Moon et al., 2010). MCs have a wide variety of cell surface receptors that play an important role in the detection of harmful pathogens. The interactions between MCs and pathogens are essential for the generation of early innate immune responses (Metz and Maurer, 2007). On appropriate activation, MCs release a multitude of biologically potent inflammatory mediators with diverse functions, and many of these MC products significantly contribute to innate immune responses (Metz and Maurer, 2009; Abraham and St John, 2010). MCs are a potential source of early response cytokines, such as tumor necrosis factor $\alpha$ (TNF- $\alpha$ ) and IL-4, that are decisive in initiating and directing the course of immune and inflammatory responses in the host (Marshall, 2004). MCs make and secrete an abundance of peptidases such as tryptases and chymases which are important and even critical for host defense and homeostasis (Trivedi and Caughey, 2010). Because of their strategic location, the presence of different types of receptors and the unique property to release potent mediators according to specific pathogen, MCs are very important effector cells in immune responses to infection.

\section{ROLE OF MAST CELLS IN BACTERIAL INFECTION}

Mast cells are by now well established to play an important role in optimal host defense in innate immune responses to bacterial infections. A number of studies have identified the critical importance of MCs in host immune defense against bacteria through the release of various substances including TNF- $\alpha$, leukotrienes, and proteases (Metz and Maurer, 2007).

In response to bacterial infection, MCs can be activated by a number of different surface molecules. For example, in the context of a bacterial infection, MCs can be activated by complement receptors, which can be directly activated by bacteria, i.e., via CD48, the receptor for FimH expressed by many bacteria (Malaviya et al., 1994, 1999), and G-protein coupled receptors for peptides such as endothelin-1 or neurotensin-1 which are upregulated during bacterial infection (Maurer et al., 2004; Galli and Tsai, 2010). Furthermore, recognition of bacterial constituents by MCs is dependent on the presence of pattern recognition receptors (PRRs), such as Toll-like receptors (TLRs), which are important in innate immune strategy. MCs express most TLRs, though there are some important speciesspecific differences in the expression and function of TLRs on MCs. TLR-ligands can directly activate MCs causing release of MC mediators in distinctive patterns (Supajatura et al., 2002; McCurdy et al., 2003; Varadaradjalou et al., 2003; Kulka et al., 2004). TLR2 and TLR4 are particularly important in mediating MC responses against bacteria. Animal models have demonstrated that TLR2-dependent MC activation contributes to the control of Mycobacterium tuberculosis infection while TLR2 ${ }^{-1-}$ mice display increased mycobacterial burden, diminished myeloid cell recruitment and pro-inflammatory cytokine production accompanied by defective granuloma formation (Carlos et al., 2009).

Different receptors expressed on MCs play important roles in the recognition of pathogens and initiate signaling pathways that result in mediator release. These mediators are crucial for host defense responses. MC-derived TNF- $\alpha$ is thought to play a significant role in recruiting neutrophils to the sites of infection. In addition, TNF- $\alpha$ has been demonstrated to provide antibacterial protection in MC-deficient mice (Malaviya et al., 1996). Interestingly, the protective effects of MCs in septic peritonitis can be enhanced by increasing the number of MCs, even in the absence 
of TNF- $\alpha$ indicating that additional MC-derived products can be important for optimal host defense (Maurer et al., 1998). Mast cells can also release their mediators without degranulation, for example LPS and peptidoglycan do not induce degranulation yet both enhance expression of promatrix metalloproteinase-9 (proMMP-9) in a dose-dependent manner (Ikeda and Funaba, 2003). Increased production of IL- 6 by MCs in response to TLR2 activation can play a crucial role in the protection against bacterial infection (Haidl et al., 2011). Infection of MCs with live Streptococci causes a TLR2- and cell-cell contact-dependent release of IL4, IL-6, IL-12, IL-13, and TNF- $\alpha$, and chemokines (CCL2/MCP-1, CCL7/MCP-3, CXCL2/MIP-2, CCL5/RANTES) (Ronnberg et al., 2010). Most of the in vivo work on MC functions in antibacterial host defense has been done using models of bacterial infections in the peritoneum; however, several publications have shown that the findings of these studies hold true in other anatomical sites such as the middle ear (Ebmeyer et al., 2005), the lung (Xu et al., 2006), and the skin (Siebenhaar et al., 2007).

It is well recognized that MCs have phagocytic capabilities, more importantly, MCs can also exhibit direct bactericidal activity, e.g., by releasing cathelicidins (Di Nardo et al., 2003) or proteases (Orinska et al., 2007). Furthermore, MCs have been shown to be able to kill bacteria by entrapping them in extracellular structures termed as mast cell extracellular trap (MCETs) composed of DNA, histones, tryptase, and cathelicidin antimicrobial peptides (von Kockritz-Blickwede et al., 2008).

\section{MAST CELL RESPONSES TO VIRAL INFECTIONS}

The contribution of MCs to host defense in viral infections is not much explored, either due to the lack of suitable mouse models of viral infection or that it has not been tested in MC deficient mouse models so far. More and more research endeavors are now focused on elucidating interactions between MCs and viruses. MCs can be activated by viruses via TLR3 (Marshall, 2004; Orinska et al., 2005). TLR3 activation decreases MC attachment to fibronectin and vitronectin and abrogates MC attachment dependent potentiation of IgE-mediated responses (Kulka and Metcalfe, 2006). MCs contribute to immune responses to viral infection by the production of type I IFNs after being exposed to doublestranded RNA and/or virus via TLR3 (Kulka et al., 2004). On the other hand, MCs stimulated via TLR3 are potent regulators of antiviral CD8+ T-cell activities in vitro and in vivo (Orinska et al., 2005). MCs release cytokines, chemokines, and lipid mediators on activation and/or infection by viruses as a protective immune response (Wedde-Beer et al., 2002; Dawicki and Marshall, 2007). Major MC mediators such as histamine, proteases, and leukotrienes are known to profoundly alter the nature of the innate immune response and its effectiveness in eliminating infection. Mediator release from MCs after viral infection is well explored as described in different reviews (Marshall et al., 2003; Metz and Maurer, 2007).

In different disease models, MCs have been shown to have a protective antiviral role. MCs sensitized with dengue virus immune sera and upon contact with Sendai virus show degranulation as well as histamine release (Sugiyama, 1977; Sanchez et al., 1986). The gp120 envelope protein of HIV can induce IL-4 and IL-13 production by MCs (Patella et al., 2000) and MC-derived interleukin-1 family cytokines exhibit protective effects against influenza virus (Kayamuro et al., 2010). MCs can selectively produce several mediators including IL-1 $\beta$, IL-6, CCL3, CCL4, and CCL5 after FcyRII-mediated dengue virus infection (King et al., 2000, 2002; Brown et al., 2006). MCs further play an important role in the clearance of dengue virus by recruitment of natural killer (NK) and NKT-cells (St John et al., 2011). Antibody-enhanced dengue virus infection among CBMCs and HMC-1 results in increased expression of the adhesion molecules ICAM-1 and VCAM-1. This effect is mediated through TNF- $\alpha$ (Brown et al., 2011). A recent report indicated the protective role of MCs against vaccinia virus by triggering its specific receptor, Sphingosine-1-phosphate receptor 2 (S1PR2), and releasing antimicrobial peptides (Wang et al., 2012). It has to be noted, that although most of these findings indicate a possible beneficial role for MCs in viral infection there may be circumstances in which the role of MCs could be detrimental. For example, Sundstrom et al. (2007) reported that HIV-infected human tissue MCs might comprise a long-lived inducible reservoir of persistent HIV in infected individuals. MCs co-cultured with respiratory syncytial virus (RSV)-infected A549 airway epithelial cells show degranulation and increased TNF- $\alpha$ secretion. It is worth mentioning that the role of MCs in response to RSV has been associated with the exacerbation or development of asthma (Shirato and Taguchi, 2009).

\section{CONTRIBUTION OF MAST CELLS IN PARASITIC INFECTION}

MCs have long been known to play a role in host defense responses against parasitic infections (Miller and Jarrett, 1971). MCs are involved in both innate and adaptive immune responses to parasites. Their ability to respond rapidly to infections by releasing pre-stored inflammatory mediators contributes to the first line of response to parasitic pathogens (Galli et al., 2008). MCs can participate in innate immunity, during local cutaneous infection with Leishmania parasites. Bone marrow-derived MCs (BMMCs) in contact with living L. major or L. infantum promastigotes reportedly release preformed mediators such as $\beta$-hexosaminidase and the preformed pool of TNF- $\alpha$ (Bidri et al., 1997). MCs can control parasites by various mechanisms, e.g., by recruitment of effector immune cells like neutrophils, regulation of gut permeability, and expulsion of parasites. MCs are preferentially located in organs targeted by parasites, e.g., the skin and gut. MCs express receptors for parasites (e.g., TLRs 1, 4, and 9), which allow MCs to react directly to parasitic stimuli. In the early response, MCs release preformed mediators that are important for the defense against parasites. MC proteases have been shown to play a pivotal role in some of these responses (Metz and Maurer, 2007). In parasite infections, the chymases mMCP-1 and mMCP-9 have, for example, been shown to contribute to the expulsion of nematodes (King et al., 2000; McDermott et al., 2003; Sasaki et al., 2005). Furthermore, histamine release from MCs via IgE-independent or IgE-mediated immune responses, is known to play a major role in parasite transmission and malaria pathogenesis (Mecheri, 2012) by causing release of nitric oxide as well as by enhancing vascular permeability (Van de Voorde and Leusen, 1983). These effects of histamine might be exploited by Plasmodium parasite to survive in its mammalian host. 
MCs are preferentially distributed throughout barrier tissues such as the skin and mucosa, including the intraepithelial space of the intestine. For instance, infection by the nematodes Strongyloides venezuelensis or Trichinella spiralis, which usually occur in the gut, induce a cytokine-dependent increase in MC numbers in the intestinal mucosa (Lantz et al., 1998; McDermott et al., 2003; Sasaki et al., 2005). Proliferation of MCs during gut helminth infection is found to be dependent on stem cell factor (Newlands et al., 1995) as well as IgE (Asai et al., 2001). MCs also appear to be vital for cutaneous immunity during the parasitic skin infection leishmaniasis, endorsing protective immunity, including $\mathrm{T}$ cell function, and controlling skin lesion size (Maurer et al., 2006).

In general, MCs are widely considered to be important late stage effector cells during Th2 associated immune responses, which includes host responses against parasitic helminths in mucosal tissues (Pennock and Grencis, 2006; Hakim-Rad et al., 2009). For example, resistance to infection is characterized by the production of IL-4, IL-5, IL-9, parasite-specific immunoglobulin G1 (IgG1) response, and higher expression of MC markers (CD117 and FceRI) as well as Th2 associated cytokines in livers of Ascaris-infected pigs (Dawson et al., 2009). T. gondii infection reportedly results in the enhancement of MCs numbers as well as influx of other effector cells like neutrophils indicating that MCs are intricately involved with the acute phase of the inflammatory response in this experimental model (Ferreira et al., 2004). MCs can exert cytotoxicity against T. gondii infection which is attributed to Leukotriene $\mathrm{B}_{4}$ produced upon activation (Henderson and Chi, 1998). MCs also contribute to protective immune responses against Plasmodium berghei in a mouse model of malaria by releasing TNF- $\alpha$ (Furuta et al., 2006), and MC-deficient mice show higher parasitemia and lower TNF- $\alpha$ as compared to wild type mice (Furuta et al., 2006).

MCs also act at the interface between innate and acquired immunity during parasitic infection. mMCP- 6 was found to be a critical link between adaptive and innate immunity in the chronic phase of T. spiralis infection (Shin et al., 2008). MCs can importantly contribute to the early innate events that determine the priming of adaptive immunity. Hepworth et al. (2012) recently described an IgE-independent role for MCs in orchestrating antiparasite type 2 immune responses involving effects of IL-25, IL-33, and TSLP.

\section{CHARACTERIZING THE ROLE OF MAST CELLS IN FUNGAL INFECTION: THE NEED OF THE HOUR}

The role of MCs in antifungal defense is an almost unexplored area of research, and in contrast to infections by bacteria, viruses, and parasites, very little is known about the relevance of MC effects in fungal infections (Maurer et al., 2006; Siebenhaar et al., 2007). This is surprising because fungi, just like other pathogens, enter the body via MC rich organs (skin, gut, airways) and because MCs express several receptors and mediators known to be involved in antifungal responses (Wedemeyer et al., 2000; Metz and Maurer, 2007). In addition, host defense responses to fungal pathogens share many characteristic features of MC-driven immune responses against bacteria and parasites (Metz et al., 2008; Metz and Maurer, 2009). Fungal infections are affecting an increasing number of people, current treatment options are not sufficient, and the mortality of invasive fungal infection remains unacceptably high. Therefore, it is important to better understand the contribution of MCs during fungal infections, as this may facilitate the development of novel and better treatment options for these diseases.

\section{SITES OF FUNGAL INFECTIONS, HINTS FROM MAST CELL DISTRIBUTION FUNGAL INFECTION IN SKIN}

Fungal skin infections are amongst the most widespread and common infections in humans. Cutaneous and superficial fungal infections are known to be caused primarily by dermatophytes, yeast and a limited number of filamentous fungi such as Aspergillus, Acremonium, Fusarium, Neoscytalidium, and Scopulariopsis (Saunte et al., 2012).

As described before in more detail, skin MCs represent one of the first inflammatory components to get in contact with pathogens and they can respond to various pathogens in many ways. By these mechanisms, MCs could, for example, contribute to antifungal immune responses by releasing IL-10 directly at the site of infection. IL-10 has been demonstrated to be important for controlling infections with several pathogenic fungi in experimental models (Romani et al., 1994; Tonnetti et al., 1995; Vecchiarelli et al., 1996; Monari et al., 1997; Fierer et al., 1998). Furthermore, MCs have also been shown to participate as IL-10 producing cells in the local immune response against Paracoccidioides brasiliensis in skin lesions characterized by a Th2 pattern of cytokines (Pagliari et al., 2006). In general, dermatomycoses are caused by filamentous fungi such as Trichophyton, Microsporum, or Epidermophyton species. These fungi, which can cause infection in human and domestic animals, have a high affinity for keratin, an important component of hair, skin, and nails. Interestingly, MCs are preferentially localized at the classical sites of cutaneous fungal infection, e.g., around hair follicles.

Other fungi potentially relevant for the skin are of the Candida species (all yeasts), of which Candida albicans is the most common. In immunocompetent persons, candidiasis is usually a localized infection of the skin or more often of the mucosal membranes, including the oral cavity (thrush), the pharynx or esophagus, the gastrointestinal tract, the urinary bladder, or the genitalia. The role of MCs in candidiasis is largely unknown, although an older report indicated that MCs could be involved in the inflammatory process, and thus possibly in the defense against the fungus by releasing histamine after activation via a glycoprotein from C. albicans (Nosal, 1974).

\section{FUNGAL INFECTION IN LUNGS}

Fungi may cause lung diseases through direct infection of pulmonary tissue, infection of pulmonary air spaces/lung cavities, or through their ability to trigger an immunological reaction when fungal materials are inhaled. Fungi are thought to serve both as immunogenic antigens and as adjuncts to inflammation 
through protease activity and are associated with allergic asthma. Aspergillus fumigatus can be regarded as the most important airborne-pathogenic fungus, and it causes the disease aspergillosis due to invasion in the lungs (Agarwal and Gupta, 2011). Fungal lung infections are more likely to be severe in people who have underlying lung disease and/or compromised immune systems such as those with HIV/AIDS. Both acute and chronic fungal infections can cause permanent lung damage and can be fatal (Boyton, 2005). Due to their strategic localization in the lung, MCs can readily interact with invading fungi and may play a protective role in different fungal disease including aspergillosis. As of now, however, there are no reports that show that MCs are importantly involved in lung fungal infections in vivo. Future research has to be carried out by employing appropriate animal models of fungal airway and lung infections in MC deficient mouse models.

\section{FUNGAL INFECTION IN THE GASTROINTESTINAL TRACT}

The gastrointestinal tract is one of the preferred sites for MCs to localize, and, in contrast to skin MCs, the number of MCs can rapidly and markedly expand during the course of an infection in the gut; this allows for a high degree of interaction between MCs and gut flora (Mikkelsen, 2010). Candida colonization is associated with several diseases of the gastrointestinal tract, e.g., Crohn's disease (Rehaume et al., 2010), ulcerative colitis (Zwolinska-Wcislo et al., 2009), and gastric ulcers (Hirasaki et al., 1999). Furthermore, results from animal models suggest that Candida colonization can delay healing of inflammatory lesions and that inflammation promotes colonization as a positive feedback mechanism. As far as the role of MCs in the gastrointestinal tract is concerned, a single report suggests that gastrointestinal Candida colonization promotes sensitization against food antigens, at least partly due to MC mediated hyper permeability of the gastrointestinal mucosa of mice (Yamaguchi et al., 2006). Although it is quite probable that MCs interact with fungi in the intestinal tract and that MCs can play an important role in host cell defense against gastrointestinal fungal infections, these issues remain to be clarified by future research.

\section{POSSIBLE MECHANISMS UNDERLYING MAST CELL INTERACTION WITH FUNGI}

The recognition of fungal pathogens induces innate immune responses through the engagement of cell surface and/or intracellular PRRs including TLRs and C-type lectin receptors (CLRs; Heinsbroek et al., 2008). TLRs and CLRs serve as sensitive sensors against fungal and other pathogens by recognizing pathogenassociated molecular patterns (PAMPs). Receptor mediated signaling cascades initiated through TLRs or CLRs ultimately provide an explanation for the kinetics and spectrum of antifungal innate immune responses (Weis et al., 1998; Kawai and Akira, 2005).

\section{PRESENCE AND IMPLICATIONS OF TLRS AND CLRS ON MAST CELLS}

Mast cells are sentinel cells of the immune system and are found in greater numbers at sites of pathogen exposure such as the skin and airways, that is favorable sites for fungi to enter the host. MCs are bestowed with different types of receptors on their surface that could be important not only in the recognition of fungal pathogens but also in the induction of antifungal responses.

Toll-like receptors, the most widely studied PRRs, are characterized structurally by the presence of a leucine rich repeat (LRR) domain in their extracellular domain and a Toll/Interleukin-1 receptor (TIR) domain in their intracellular domain. Activation of TLRs leads to the production of cytokines, chemokines, and antimicrobial peptides and to the upregulation of stimulatory and adhesion molecules in a large array and variety of cells involved in innate immune responses (Miller and Modlin, 2007). MCs, depending on the subtype and tissue distribution pattern, differentially express TLRs (Matsushima et al., 2004). Murine connective tissue type MCs express TLR3, TLR7, and TLR9 mRNA. In contrast, BMMCs only marginally express TLR3, TLR7, and TLR9 mRNA (Matsushima et al., 2004). Human MCs also express TLR1 and 6 (McCurdy et al., 2001, 2003), TLR3 (Kulka et al., 2004), TLR7 (Kulka et al., 2004; Matsushima et al., 2004), and TLR9 (Zhu and Marshall, 2001) whereas the expression of TLR5 by MCs remains controversial. Other than TLRs, MCs also express different type of CLRs that are also crucial for antifungal responses.

C-type lectin receptors comprise a large family of receptors that bind to carbohydrates in a calcium-dependent manner. The lectin activity of these receptors is mediated by conserved carbohydraterecognition domains (CRDs). CLRs include Dectin-1, Dectin-2, macrophage-inducible C-type lectin (Mincle), and the dendritic cell-specific ICAM3-grabbing non-integrin (DC-SIGN). CLRs are involved in fungal recognition and in the modulation of antifungal innate immune responses. They are expressed by most cell types including MCs, macrophages, and DCs (Willment and Brown, 2008; Geijtenbeek and Gringhuis, 2009).

Human MCs (Olynych et al., 2006) as well as murine MCs (Yang and Marshall, 2009) express the Dectin-1 receptor on their surface. Dectin-1 plays a crucial role in the generation of reactive oxygen species (ROS) through zymosan. MCs can also express the macrophage-inducible C-type lectin receptor Mincle (Ribbing et al., 2011). TLRs and CLRs play a significant role in antifungal responses of MCs as described below.

\section{ROLE OF TLRS IN RECOGNITION OF FUNGAL COMPONENTS}

Toll-like receptors, especially TLR2 and TLR4, have been implicated in the recognition of fungal pathogens such as C. albicans, A. fumigatus, Cryptococcus neoformans, and Pneumocystis carinii. Moreover, several PAMPs located in the cell wall or cell surface of fungi have been identified as potential TLR-ligands. For example, yeast zymosan activates TLR2/TLR6 heterodimers, whereas C. albicans phospholipomannan is recognized by TLR2 (Jouault et al., 2003) and glucuronoxylomannan, the major capsular polysaccharide of C. neoformans, binds to TLR4 (Shoham et al., 2001).

Toll-like receptor-4 signals are important for the recognition of fungal pathogens and their absence may allow for the persistence of infection. TLR4-defective mice, for example, are more susceptible to C. albicans infection and show reduced chemokine expression and neutrophil recruitment as compared to wild type mice (Netea et al., 2002). The absence of functional TLR4 results 
in lower chemotaxis of neutrophils to the site of infection, lower levels of TNF- $\alpha$, CXCL1 and nitric oxide, and dissemination and persistence of the pathogen in lymph nodes and spleen (Gasparoto et al., 2010). Candida binding to TLR2, along with activation of dectin-1 (fungal pathogen-recognition receptor), synergistically induces the production of cytokines such as IL-12 and TNF- $\alpha$ in macrophages (Gantner et al., 2003). TLR2 is also involved as a mediator in $\mathrm{PGE}_{2}$ production in response to C. albicans by upregulating COX-2 expression (Villamon et al., 2005). Infection of C. albicans in TLR2 ${ }^{-1-}$ mice results in reduced Th1 cytokine production as compared to control mice. On the other hand, TLR2 ${ }^{-1-}$ mice reportedly show normal Candida-specific humoral responses and develop normal vaccine-induced resistance (Villamon et al., 2004b). TLR9 is another relevant pathogen-recognition receptor for C. albicans (Kasperkovitz et al., 2011). TLR9-deficient (TLR9 $^{-1-}$ ) mice show a $20-30 \%$ reduction in cytokine production induced by $C$. albicans in PBMCs (van de Veerdonk et al., 2008).

All TLRs, except TLR3, appear to be coupled to the adapter protein myeloid differentiation primary response gene 88 (MyD88). TLR-mediated fungal recognition may be through MyD88dependent (O'Neill, 2003) or independent pathways (Yamamoto et al., 2003). For example, the recruitment of neutrophils to the site of C. albicans infection is significantly diminished in $\mathrm{MyD} 88^{-1-}$ mice (Villamon et al., 2004a). As of yet, no studies have investigated the possible role of TLR3 or MyD88 independent pathways in the host response to C. albicans infection (Netea et al., 2008). For Aspergillus, MyD88-deficient mice survived the infection suggesting a MyD88-independent pathway (Bellocchio et al., 2004).
Taken together, it appears that MCs are readily equipped with TLRs and with the necessary downstream signaling intermediates to translate fungal pathogen detection to protective immune responses.

\section{ROLE OF C-TYPE LECTIN-LIKE RECEPTORS IN THE RECOGNITION OF FUNGAL COMPONENTS}

Many members of this large receptor family participate in the recognition of fungal PAMPs in a calcium-dependent fashion (e.g., dectin-1, dectin-2, Mincle, DC-SIGN/CD209, and mannose receptor/CD206). Dectin-1 specifically recognizes soluble or particulate $\beta$-1,3- and/or $\beta$-1,6-glucans, which are found in the cell walls of fungi (Yadav and Schorey, 2006). Dectin-1 is a key receptor involved in mediating the biological effects of $\beta$-glucans and centrally involved in the innate response to fungal pathogens. A variety of clinically important fungal pathogens are recognized by dectin-1, e.g., C. albicans and P. carinii. Dectin-1 is expressed in innate immune cells such as macrophages, neutrophils, DCs, and MCs. Dectin-1 overexpression results in enhanced binding of $P$. carinii to macrophages (Steele et al., 2003), and dectin-1 importantly contributes to the protection against $P$. carinii by generating ROS (Saijo and Iwakura, 2011). Dectin-1 expression in MCs and the induction of dectin-1-dependent ROS production are also enhanced by zymosan treatment (Yang and Marshall, 2009). The generation of ROS is known to be essential in the formation of neutrophil extracellular traps (NETs) to kill microbes (Brinkmann et al., 2004). NETs can kill both yeast and hyphal forms of C. albicans (Urban et al., 2006), and since MCs also have the ability to generate ROS as well as to form extracellular traps (von Kockritz-Blickwede et al., 2008), MCs may

Table 1 | Possible mechanism of fungal recognition by mast cells.

\begin{tabular}{|c|c|c|c|c|c|c|c|}
\hline $\begin{array}{l}\text { Fungal } \\
\text { species }\end{array}$ & $\begin{array}{l}\text { Host } \\
\text { (human/mice) }\end{array}$ & Cell type & $\begin{array}{l}\text { Fungal } \\
\text { signal (PAMP) }\end{array}$ & $\begin{array}{l}\text { Receptor or } \\
\text { adaptor protein }\end{array}$ & $\begin{array}{l}\text { Cellular } \\
\text { response }\end{array}$ & $\begin{array}{l}\text { Study } \\
\text { type }\end{array}$ & Reference \\
\hline S. cerevisiae & Mouse & BMMCs & Zymosan & Dectin-1 & $\begin{array}{l}\text { Reactive oxygen } \\
\text { species (ROS) }\end{array}$ & In vitro & $\begin{array}{l}\text { Yang and Marshall } \\
\text { (2009) }\end{array}$ \\
\hline S. cerevisiae & Human & CBMCs & Zymosan & Dectin-1 & LTB4, LTC4 & In vitro & $\begin{array}{l}\text { Olynych et al. } \\
\text { (2006) }\end{array}$ \\
\hline S. cerevisiae & Human & CBMCs & Zymosan & TLR2 & $\begin{array}{l}\text { GM-CSF and IL-1 } \beta \text {, } \\
\text { Cys LT }\end{array}$ & In vitro & $\begin{array}{l}\text { McCurdy et al. } \\
\text { (2003) }\end{array}$ \\
\hline $\begin{array}{l}\text { Aspergillus } \\
\text { fumigatus }\end{array}$ & Rat & $\mathrm{RBL}-2 \mathrm{H} 3$ & $\begin{array}{l}\text { A. fumigatus } \\
\text { hyphae }\end{array}$ & $\begin{array}{l}\text { StuA and MedA } \\
\text { (Regulator) }\end{array}$ & $\beta$-Hexosaminidase & In vitro & Urb et al. (2009) \\
\hline $\begin{array}{l}\text { Aspergillus } \\
\text { oryzae }\end{array}$ & Rat & $\mathrm{RBL}-2 \mathrm{H} 3$ & $\begin{array}{l}\text { Aspergillus } \\
\text { oryzae lectin } \\
\text { (AOL) }\end{array}$ & $\mathrm{Fc \varepsilon RI}$ & $\beta$-Hexosaminidase & In vitro & $\begin{array}{l}\text { Yamaki and } \\
\text { Yoshino (2011) }\end{array}$ \\
\hline $\begin{array}{l}\text { Malassezia } \\
\text { sympodialis }\end{array}$ & Mouse & BMMCs & $\begin{array}{l}\text { Malassezia } \\
\text { sympodialis } \\
\text { extract }\end{array}$ & TLR2/MyD88 & $\begin{array}{l}\text { IL-6 (Enhancement of } \\
\text { secretion in lgE } \\
\text { receptor cross-linked } \\
\text { BMMCs) }\end{array}$ & In vitro & $\begin{array}{l}\text { Selander et al. } \\
\text { (2009) }\end{array}$ \\
\hline M. sympodialis & Human & Peripheral blood MCs & $\begin{array}{l}\text { M. } \\
\text { sympodialis } \\
\text { extract }\end{array}$ & Dectin-1 & IL-6, IL-8 & In vitro & $\begin{array}{l}\text { Ribbing et al. } \\
\text { (2011) }\end{array}$ \\
\hline
\end{tabular}

Abbreviations: BMMCs, bone marrow-derived mast cells; CBMCs, cord blood-derived mast cells; RBL-2H3, rat basophilic leukemia cells 


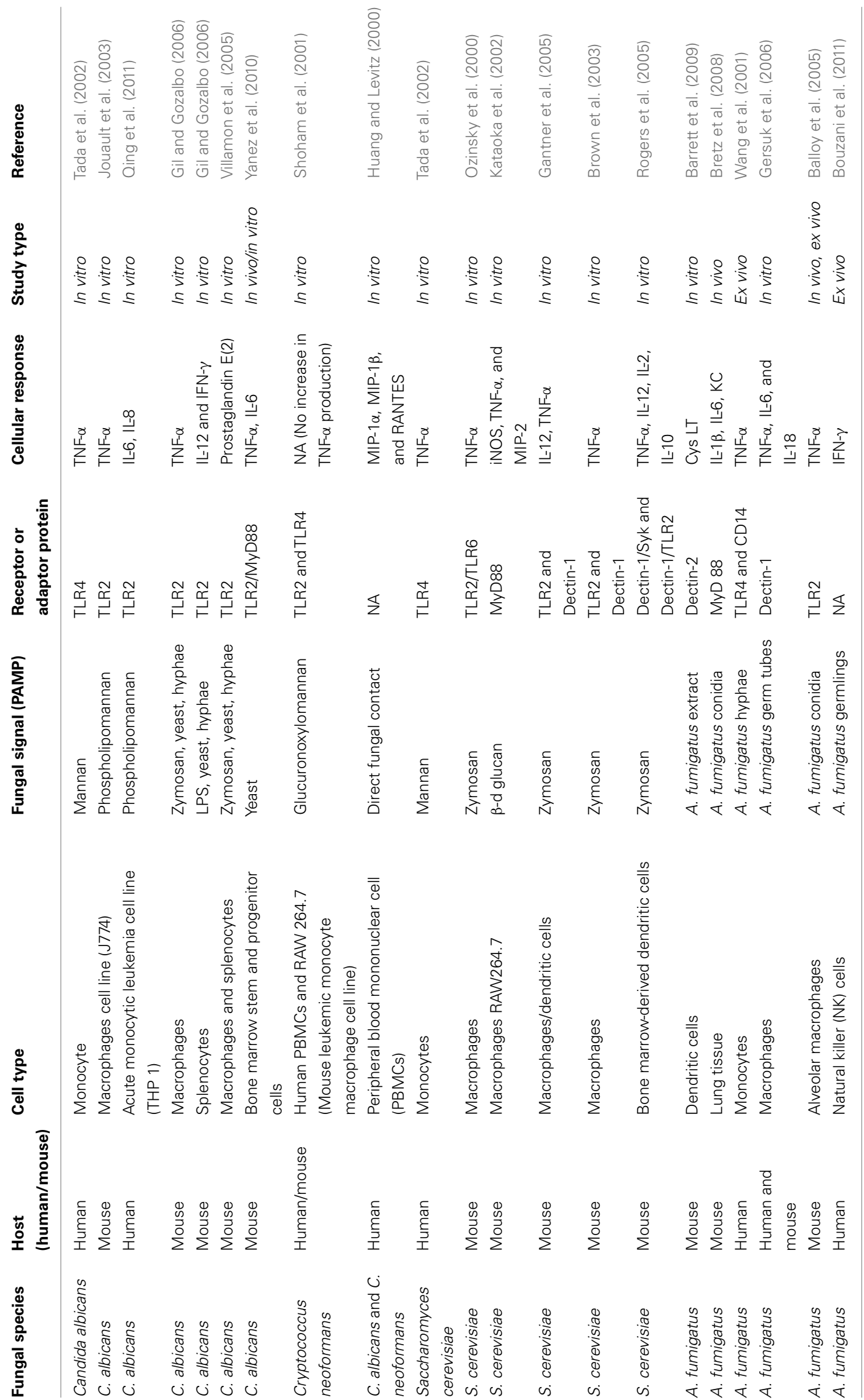


contribute to the protection against C. albicans infection by similar mechanisms.

Dectin-2 recognizes fungi and induces immune responses via the activation of the $\operatorname{FcR} \gamma$ chain, which results in the internalization of fungus compounds and induces secretion of TNF- $\alpha$ (Sato et al., 2006). Dectin-2 recognizes high mannose structures of many fungi, including C. albicans, Saccharomyces cerevisiae, Histoplasma capsulatum, P. brasiliensis, Trichophyton rubrum (Graham and Brown, 2009), and A. fumigatus (Barrett et al., 2009). Dectin-2 along with FcR $\gamma$ also plays an important role in the recognition of house dust mite (Dermatophagoides farina) and triggers cysteinyl leukotriene generation by MCs (Barrett et al., 2009). Dectin-2 is also crucial in host defense against C. albicans by inducing Th17 cell differentiation (Saijo et al., 2010).

All CLRs are coupled to Syk kinase, which allows these receptors to signal via CARD9 leading to NF- $\kappa$ B activation, which in turn contributes to the induction of both innate and adaptive immunity against fungal pathogens (Drummond et al., 2011). CARD9 and Syk regulate different signaling events in which CARD9 mediates $\mathrm{I} \kappa \mathrm{B} \alpha$ kinase ubiquitination, whereas Syk regulates IкB $\alpha$ kinase phosphorylation (Bi et al., 2010). CARD9 is expressed in MCs albeit at lower levels than in macrophages, DCs, and neutrophils (Hara et al., 2007). A comprehensive summary of fungal pathogens, their signal (PAMP) demonstrated to activate MCs or other cell types in vitro/in vivo, as well as known receptors or adapter proteins are listed in Tables $\mathbf{1}$ and $\mathbf{2}$.

\section{MAST CELL MEDIATOR RELEASE IN RESPONSE TO FUNGAL INFECTION}

MCs release several classes of preformed and de novo synthesized mediators. Preformed MC products are released by degranulation and include histamine and proteases. In contrast to bacterial infections, where MCs appear to contribute to host defense mainly by the release of preformed mediators (e.g., histamine, proteoglycans, and proteases), in fungal infections it is the de novo synthesized mediators that may come out to be protective, although in some cases preformed mediators may also play an important role. For example, A. fumigatus hyphae can induce MC degranulation in the absence of IgE (Urb et al., 2009) while on the other hand $A$. fumigatus conidia lack the ability to degranulate MCs. Yamaki and Yoshino (2011) demonstrated that Aspergillus oryzae lectin (AOL), a fucose-specific lectin, induces anaphylactic reactions and $\mathrm{MC}$ activation. AOL induces the release of $\beta$-hexosaminidase from the rat basophilic leukemia cell line RBL-2H3 sensitized with IgE, suggesting the possible implication of $\mathrm{AOL}$ in the allergic response to A. oryzae in humans.

MCs employ many de novo synthesized mediators including IL- 6 , IL- 8 , IL- $1 \beta$, IFN- $\gamma$, MIP- $1 \alpha$, and MIP- $1 \beta$. Many of these mediators have been shown to be involved in protective host responses to fungal pathogens. For example, IFN$\gamma$ plays a critical role in the control of invasive aspergillosis (Warris et al., 2005). MIP- $1 \alpha$ is required for the efferent phase of pulmonary cell-mediated immunity to $C$. neoformans infection (Huffnagle et al., 1997). Thus, it appears likely that MC-derived de novo synthesized cytokines and chemokines can contribute to antifungal innate immune responses. Newly formed MC lipid mediators may also be involved in fungal infection. Fungal zymosan can induce leukotriene production (LTB4 and LTC4) by human MCs through a dectin-1-dependent mechanism. Yeast zymosan, a potent inducer of GM-CSF and IL-1 $\beta$, can also induce substantial short-term cysteinyl leukotriene generation and can lead to the production of ROS which may have an important role in the defense against fungal infection, an area which needs to be explored more systematically in vivo (Yang and Marshall, 2009). The role of fungal components in the activation of MCs or other cell types and their mediator release is summarized in Tables 1 and 2.

MCs have been reported release of mediators during antifungal immune responses in vivo, for example against $P$. brasiliensis in skin lesions with loose granuloma and a Th2 pattern of cytokines. MCs also appear to be a source of IL-10 in paracoccidioidomycosis skin lesions (Pagliari et al., 2006). Selander et al. (2009) demonstrated that M. sympodialis extract causes release of cysteinyl leukotrienes from non-sensitized MCs. It can also enhance MC IgE-dependent activation, and alters IL- 6 production in mouse MCs. In peripheral blood MCs from atopic eczema patients, increased amounts of IL6 is released after $24 \mathrm{~h}$ stimulation with M. sympodialis extract with or without simultaneous IgE receptor cross-linking (Ribbing et al., 2011). These reports further support an important role for de novo synthesized MC mediators during antifungal host responses.

\section{CONCLUSION AND OUTLOOK}

Our understanding of the role and relevance of MCs in raising host immune responses to pathogens has improved considerably over the last 15 years. We now know that MCs are crucial for protection in many models of bacterial, viral, and parasite infections. In contrast, we know very little about the role of MCs in fungal infections. This is surprising as there are several independent lines of evidence that point towards critical effects of MCs in antifungal host defense responses: MCs are strategically located to encounter invading fungal pathogens, and they are equipped with various receptors to detect them and to become activated in response to them. Also, MCs produce a large array of mediators, many of which have been shown to contribute to antifungal host defense.

The ultimate goal of future research should be to translate findings from animal models of fungal infection into new treatment regimes for patients who are vulnerable to lethal fungal infections. Therefore, in this review, we have presented an overall view of MCs response to bacterial, viral, and parasitic infections, and we have given insights into possible defense strategies that could come into play during fungal infection. We emphasize the need to characterize the role of MCs in host defense responses against fungal infections. It is the need of the hour to direct our attention to the physiological and beneficial functions of MCs and to re-evaluate them as potentially powerful players in immune responses against infectious fungi. Thorough research in this direction may lead to novel and improved therapeutic interventions to combat fungal infections and to reduce their morbidity and mortality. 


\section{REFERENCES}

Abraham, S. N., and St John, A. L. (2010). Mast cell-orchestrated immunity to pathogens. Nat. Rev. Immunol. 10, 440-452.

Agarwal, R., and Gupta, D. (2011). Severe asthma and fungi: current evidence. Med. Mycol. 49(Suppl. 1), S150-S157.

Asai, K., Kitaura, J., Kawakami, Y., Yamagata, N., Tsai, M., Carbone, D. P., Liu, F. T., Galli, S. J., and Kawakami, T. (2001). Regulation of mast cell survival by IgE. Immunity 14 , 791-800.

Balloy, V., SI-Tahar, M., Takeuchi, O., Philippe, B., Nahori, M. A., Tanguy, M., Huerre, M., Akira, S., Latge, J. P., and Chignard, M. (2005). Involvement of toll-like receptor 2 in experimental invasive pulmonary aspergillosis. Infect. Immun. 73, 5420-5425.

Barrett, N. A., Maekawa, A., Rahman, O. M., Austen, K. F., and Kanaoka, Y. (2009). Dectin-2 recognition of house dust mite triggers cysteinyl leukotriene generation by dendritic cells. J. Immunol. 182, 1119-1128.

Bellocchio, S., Montagnoli, C., Bozza, S., Gaziano, R., Rossi, G., Mambula, S. S., Vecchi, A., Mantovani, A., Levitz, S. M., and Romani, L. (2004). The contribution of the Toll-like/IL1 receptor superfamily to innate and adaptive immunity to fungal pathogens in vivo. J. Immunol. 172, 3059-3069.

Bi, L., Gojestani, S., Wu, W., Hsu, Y. M., Zhu, J., Ariizumi, K., and Lin, X. (2010). CARD9 mediates dectin-2induced IkappaBalpha kinase ubiquitination leading to activation of NF-kappaB in response to stimulation by the hyphal form of Candida albicans. J. Biol. Chem. 285, 25969-25977.

Bidri, M., Vouldoukis, I., Mossalayi, M. D., Debre, P., Guillosson, J. J., Mazier, D., and Arock, M. (1997). Evidence for direct interaction between mast cells and Leishmania parasites. Parasite Immunol. 19, 475-483.

Bouzani, M., Ok, M., McCormick, A., Ebel, F., Kurzai, O., Morton, C. O., Einsele, H., and Loeffler, J. (2011). Human NK cells display important antifungal activity against Aspergillus fumigatus, which is directly mediated by IFN-gamma release. J. Immunol. 187, 1369-1376.

Boyton, R. J. (2005). Infectious lung complications in patients with HIV/AIDS. Curr. Opin. Pulm. Med. 11, 203-207.

Bretz, C., Gersuk, G., Knoblaugh, S., Chaudhary, N., Randolph-Habecker, J., Hackman, R. C., Staab, J., and
Marr, K. A. (2008). MyD88 signaling contributes to early pulmonary responses to Aspergillus fumigatus. Infect. Immun. 76, 952-958.

Brinkmann, V., Reichard, U., Goosmann, C., Fauler, B., Uhlemann, Y., Weiss, D. S., Weinrauch, Y., and Zychlinsky, A. (2004). Neutrophil extracellular traps kill bacteria. Science 303, 1532-1535.

Brown, G. D., Herre, J., Williams, D. L., Willment, J. A., Marshall, A. S., and Gordon, S. (2003). Dectin1 mediates the biological effects of beta-glucans. J. Exp. Med. 197, 1119-1124.

Brown, M. G., Hermann, L. L., Issekutz, A. C., Marshall, J. S., Rowter, D., ALAfif, A., and Anderson, R. (2011). Dengue virus infection of mast cells triggers endothelial cell activation. J. Virol. 85, 1145-1150.

Brown, M. G., King, C. A., Sherren, C., Marshall, J. S., and Anderson, R. (2006). A dominant role for FcgammaRII in antibodyenhanced dengue virus infection of human mast cells and associated CCL5 release. J. Leukoc. Biol. 80, 1242-1250.

Carlos, D., Frantz, F. G., SOUZA-Junior, D. A., Jamur, M. C., Oliver, C., Ramos, S. G., Quesniaux, V. F., Ryffel, B., Silva, C. L., Bozza, M. T., and Faccioli, L. H. (2009). TLR2-dependent mast cell activation contributes to the control of Mycobacterium tuberculosis infection. Microbes Infect. 11, 770-778.

Dawicki, W., and Marshall, J. S. (2007). New and emerging roles for mast cells in host defence. Curr. Opin. Immunol. 19, 31-38.

Dawson, H., Solano-Aguilar, G., Beal, M., Beshah, E., Vangimalla, V., Jones, E., Botero, S., and Urban, J. F. Jr. (2009). Localized Th1-, Th2-, T regulatory cell-, and inflammationassociated hepatic and pulmonary immune responses in Ascaris suuminfected swine are increased by retinoic acid. Infect. Immun. 77, 2576-2587.

Di Nardo, A., Vitiello, A., and Gallo, R. L. (2003). Cutting edge: mast cell antimicrobial activity is mediated by expression of cathelicidin antimicrobial peptide. J. Immunol. 170, 2274-2278.

Drummond, R. A., Saijo, S., Iwakura, Y., and Brown, G. D. (2011). The role of Syk/CARD9 coupled C-type lectins in antifungal immunity. Eur. J. Immunol. 41, 276-281.

Ebmeyer, J., Furukawa, M., Pak, K., Ebmeyer, U., Sudhoff, H., Broide, D., Ryan, A. F., and Wasserman, S. (2005). Role of mast cells in otitis media. J. Allergy Clin. Immunol. 116, 1129-1135.

Fierer, J., Walls, L., Eckmann, L., Yamamoto, T., and Kirkland, T. N. (1998). Importance of interleukin10 in genetic susceptibility of mice to Coccidioides immitis. Infect. Immun. 66, 4397-4402.

Furuta, T., Kikuchi, T., Iwakura, Y., and Watanabe, N. (2006). Protective roles of mast cells and mast cellderived TNF in murine malaria. J. Immunol. 177, 3294-3302.

Galli, S. J., Grimbaldeston, M., and Tsai, M. (2008). Immunomodulatory mast cells: negative, as well as positive, regulators of immunity. Nat. Rev. Immunol. 8, 478-486.

Galli, S. J., Kalesnikoff, J., Grimbaldeston, M. A., Piliponsky, A. M., Williams, C. M., and Tsai, M. (2005). Mast cells as "tunable" effector and immunoregulatory cells: recent advances. Annu. Rev. Immunol. 23, 749-786.

Galli, S. J., and Tsai, M. (2010). Mast cells in allergy and infection: versatile effector and regulatory cells in innate and adaptive immunity. Eur. J. Immunol. 40, 1843-1851.

Gantner, B. N., Simmons, R. M., Canavera, S. J., Akira, S., and Underhill, D. M. (2003). Collaborative induction of inflammatory responses by dectin-1 and Tolllike receptor 2. J. Exp. Med. 197, 1107-1117.

Gantner, B. N., Simmons, R. M., and Underhill, D. M. (2005). Dectin1 mediates macrophage recognition of Candida albicans yeast but not filaments. EMBO J. 24, 1277-1286.

Gasparoto, T. H., Tessarolli, V., Garlet, T. P., Torres, S. A., Garlet, G. P., da Silva, J. S., and Campanelli, A. P. (2010). Absence of functional TLR4 impairs response of macrophages after Candida albicans infection. Med. Mycol. 48, 1009-1017.

Geijtenbeek, T. B., and Gringhuis, S. I. (2009). Signalling through C-type lectin receptors: shaping immune responses. Nat. Rev. Immunol. 9, 465-479.

Gersuk, G. M., Underhill, D. M., Zhu, L. and Marr, K. A. (2006). Dectin-1 and TLRs permit macrophages to distinguish between different Aspergillus fumigatus cellular states. J. Immunol. 176, 3717-3724.

Gil, M. L., and Gozalbo, D. (2006). TLR2, but not TLR4, triggers cytokine production by murine cells in response to Candida albicans yeasts and hyphae. Microbes Infect. 8, 2299-2304.

Ferreira, G. L. S., Mineo, J. R., Oliveira, J. G., Ea, V. F., Souza, M. A., and
Aa, D. S. (2004). Toxoplasma gondii and mast cell interactions in vivo and in vitro: experimental infection approaches in Calomys callosus (Rodentia, Cricetidae). Microbes Infect. 6, 172-181.

Graham, L. M., and Brown, G. D. (2009). The Dectin-2 family of Ctype lectins in immunity and homeostasis. Cytokine 48, 148-155.

Haidl, I. D., McAlpine, S. M., and Marshall, J. S. (2011). Enhancement of mast cell IL-6 production by combined toll-like and nucleotidebinding oligomerization domainlike receptor activation. Int. Arch. Allergy Immunol. 154, 227-235.

Hakim-Rad, K., Metz, M., and Maurer, M. (2009). Mast cells: makers and breakers of allergic inflammation. Curr. Opin. Allergy Clin. Immunol. 9, 427-430.

Hara, H., Ishihara, C., Takeuchi, A., Imanishi, T., Xue, L., Morris, S. W., Inui, M., Takai, T., Shibuya, A., Saijo S., Iwakura, Y., Ohno, N., Koseki, H., Yoshida, H., Penninger, J. M., and Saito, T. (2007). The adaptor protein CARD9 is essential for the activation of myeloid cells through ITAMassociated and Toll-like receptors. Nat. Immunol. 8, 619-629.

Heinsbroek, S. E., Taylor, P. R., Martinez, F. O., Martinez-Pomares, L. Brown, G. D., and Gordon, S. (2008). Stage-specific sampling by pattern recognition receptors during Candida albicans phagocytosis. PLoS Pathog. 4, e1000218. doi:10.1371/journal.ppat.1000218

Henderson, W. R. Jr., and Chi, E. Y. (1998). The importance of leukotrienes in mast cell-mediated Toxoplasma gondii cytotoxicity. J. Infect. Dis. 177, 1437-1443.

Hepworth, M. R., Danilowicz-Luebert, E., Rausch, S., Metz, M., Klotz, C., Maurer, M., and Hartmann, S. (2012). Mast cells orchestrate type 2 immunity to helminths through regulation of tissue-derived cytokines. Proc. Natl. Acad. Sci. U. S. A. 109, 6644-6649.

Hirasaki, S., Koide, N., Ogawa, H., and Tsuji, T. (1999). Benign gastric ulcer associated with Canidida infection in a healthy adult. J. Gastroenterol. 34, 688-693.

Huang, C., and Levitz, S. M. (2000). Stimulation of macrophage inflammatory protein-1alpha, macrophage inflammatory protein-1beta, and RANTES by Candida albicans and Cryptococcus neoformans in peripheral blood mononuclear cells from persons with and without human immunodeficiency virus infection. $J$. Infect. Dis. 181, 791-794. 
Huffnagle, G. B., Strieter, R. M., McNeil, L. K., McDonald, R. A., Burdick, M. D., Kunkel, S. L., and Toews, G. B. (1997). Macrophage inflammatory protein-1alpha (MIP-1alpha) is required for the efferent phase of pulmonary cell-mediated immunity to a Cryptococcus neoformans infection. J. Immunol. 159, 318-327.

Ikeda, T., and Funaba, M. (2003). Altered function of murine mast cells in response to lipopolysaccharide and peptidoglycan. Immunol. Lett. 88, 21-26.

Jouault, T., Ibata-Ombetta, S., Takeuchi, O., Trinel, P. A., Sacchetti, P., Lefebvre, P., Akira, S., and Poulain, D. (2003). Candida albicans phospholipomannan is sensed through tolllike receptors. J. Infect. Dis. 188, 165-172.

Kasperkovitz, P. V., Khan, N. S., Tam, J. M., Mansour, M. K., Davids, P. J., and Vyas, J. M. (2011). Toll-like receptor 9 modulates macrophage antifungal effector function during innate recognition of Candida albicans and Saccharomyces cerevisiae. Infect. Immun. 79, 4858-4867.

Kataoka, K., Muta, T., Yamazaki, S., and Takeshige, K. (2002). Activation of macrophages by linear (1right-arrow3)-beta-D-glucans. Impliations for the recognition of fungi by innate immunity. J. Biol. Chem. 277, 36825-36831.

Kawai, T., and Akira, S. (2005). Pathogen recognition with Toll-like receptors. Curr. Opin. Immunol. 17, 338-344.

Kayamuro, H., Yoshioka, Y., Abe, Y., Arita, S., Katayama, K., Nomura, T., Yoshikawa, T., Kubota-Koketsu, R., Ikuta, K., Okamoto, S., Mori, Y., Kunisawa, J., Kiyono, H., Itoh, N., Nagano, K., Kamada, H., Tsutsumi, Y., and Tsunoda, S. (2010). Interleukin-1 family cytokines as mucosal vaccine adjuvants for induction of protective immunity against influenza virus. J. Virol. 84, 12703-12712.

King, C. A., Anderson, R., and Marshall, J. S. (2002). Dengue virus selectively induces human mast cell chemokine production. J. Virol. 76, 8408-8419.

King, C. A., Marshall, J. S., Alshurafa, H., and Anderson, R. (2000). Release of vasoactive cytokines by antibodyenhanced dengue virus infection of a human mast cell/basophil line. $J$. Virol. 74, 7146-7150.

Kulka, M., Alexopoulou, L., Flavell, R. A., and Metcalfe, D. D. (2004). Activation of mast cells by doublestranded RNA: evidence for activation through Toll-like receptor 3. $J$. Allergy Clin. Immunol. 114, 174-182.
Kulka, M., and Metcalfe, D. D. (2006). TLR3 activation inhibits human mast cell attachment to fibronectin and vitronectin. Mol. Immunol. 43, 1579-1586.

Lantz, C. S., Boesiger, J., Song, C. H., Mach, N., Kobayashi, T., Mulligan, R. C., Nawa, Y., Dranoff, G., and Galli, S. J. (1998). Role for interleukin-3 in mast-cell and basophil development and in immunity to parasites. Nature 392, 90-93.

Malaviya, R., Gao, Z., Thankavel, K., Van der Merwe, P. A., and Abraham, S. N. (1999). The mast cell tumor necrosis factor alpha response to FimH-expressing Escherichia coli is mediated by the glycosylphosphatidylinositolanchored molecule CD48. Proc. Natl. Acad. Sci. U.S.A. 96, 8110-8115.

Malaviya, R., Ikeda, T., Ross, E., and Abraham, S. N. (1996). Mast cell modulation of neutrophil influx and bacterial clearance at sites of infection through TNF-alpha. Nature $381,77-80$.

Malaviya, R., Ross, E. A., Macgregor, J. I., Ikeda, T., Little, J. R., Jakschik, B. A., and Abraham, S. N. (1994). Mast cell phagocytosis of FimH-expressing enterobacteria. $J$. Immunol. 152, 1907-1914.

Marshall, J. S. (2004). Mast-cell responses to pathogens. Nat. Rev. Immunol. 4, 787-799.

Marshall, J. S., King, C. A., and McCurdy, J. D. (2003). Mast cell cytokine and chemokine responses to bacterial and viral infection. Curr. Pharm. Des. 9, 11-24.

Matsushima, H., Yamada, N., Matsue, H., and Shimada, S. (2004). TLR3-, TLR7-, and TLR9-mediated production of proinflammatory cytokines and chemokines from murine connective tissue type skin-derived mast cells but not from bone marrowderived mast cells. J. Immunol. 173, 531-541.

Maurer, M., Echtenacher, B., Hultner, L., Kollias, G., Mannel, D. N., Langley, K. E., and Galli, S. J. (1998). The c-kit ligand, stem cell factor, can enhance innate immunity through effects on mast cells. J. Exp. Med. 188, 2343-2348.

Maurer, M., Lopez Kostka, S., Siebenhaar, F., Moelle, K., Metz, M., Knop, J., and Von Stebut, E. (2006). Skin mast cells control T cell-dependent host defense in Leishmania major infections. FASEB J. 20, 2460-2467.

Maurer, M., Wedemeyer, J., Metz, M., Piliponsky, A. M., Weller, K., Chatterjea, D., Clouthier, D. E., Yanagisawa, M. M., Tsai, M., and Galli,
S. J. (2004). Mast cells promote homeostasis by limiting endothelin1-induced toxicity. Nature 432 512-516.

McCurdy, J. D., Lin, T. J., and Marshall, J. S. (2001). Toll-like receptor 4mediated activation of murine mast cells. J. Leukoc. Biol. 70, 977-984.

McCurdy, J. D., Olynych, T. J., Maher, L. H., and Marshall, J. S. (2003). Cutting edge: distinct Toll-like receptor 2 activators selectively induce different classes of mediator production from human mast cells. J. Immunol. 170, 1625-1629.

McDermott, J. R., Bartram, R. E., Knight, P. A., Miller, H. R., Garrod, D. R., and Grencis, R. K. (2003). Mast cells disrupt epithelial barrier function during enteric nematode infection. Proc. Natl. Acad. Sci. U.S.A. 100 7761-7766.

Mecheri, S. (2012). Contribution of allergic inflammatory response to the pathogenesis of malaria disease. Biochim. Biophys. Acta 1822, 49-56.

Metz, M., and Maurer, M. (2007). Mast cells - key effector cells in immune responses. Trends Immunol. 28, 234-241.

Metz, M., and Maurer, M. (2009). Innate immunity and allergy in the skin. Curr. Opin. Immunol. 21, 687-693.

Metz, M., Siebenhaar, F., and Maurer, M. (2008). Mast cell functions in the innate skin immune system. Immunobiology 213, 251-260.

Mikkelsen, H. B. (2010). Interstitial cells of Cajal, macrophages and mast cells in the gut musculature: morphology, distribution, spatial and possible functional interactions. J. Cell. Mol. Med. 14, 818-832.

Miller, H. R., and Jarrett, W. F. (1971). Immune reactions in mucous membranes. I. Intestinal mast cell response during helminth expulsion in the rat. Immunology 20, 277-288.

Miller, L. S., and Modlin, R. L. (2007). Toll-like receptors in the skin. Semin. Immunopathol. 29, 15-26.

Monari, C., Retini, C., Palazzetti, B., Bistoni, F., and Vecchiarelli, A. (1997). Regulatory role of exogenous IL10 in the development of immune response versus Cryptococcus neoformans. Clin. Exp. Immunol. 109, 242-247.

Moon, T. C., St Laurent, C. D., Morris, K. E., Marcet, C., Yoshimura, T., Sekar, Y., and Befus, A. D. (2010). Advances in mast cell biology: new understanding of heterogeneity and function. Mucosal Immunol. 3, 111-128.

Netea, M. G., Brown, G. D., Kullberg, B. J., and Gow, N. A. (2008). An integrated model of the recognition of Candida albicans by the innate immune system. Nat. Rev. Microbiol. 6, 67-78.

Netea, M. G., van der Graaf, C. A., Vonk, A. G., Verschueren, I., van der Meer, J. W., and Kullberg, B. J. (2002). The role of toll-like receptor (TLR) 2 and TLR4 in the host defense against disseminated candidiasis. J. Infect. Dis. 185, 1483-1489.

Newlands, G. F., Coulson, P. S., and Wilson, R. A. (1995). Stem cell factor dependent hyperplasia of mucosaltype mast cells but not eosinophils in Schistosoma mansoni-infected rats. Parasite Immunol. 17, 595-598.

Nosal, R. (1974). Histamine release from isolated rat mast cells due to glycoprotein from Candida albicans in vitro. J. Hyg. Epidemiol. Microbiol. Immunol. 18, 377-378.

Olynych, T. J., Jakeman, D. L., and Marshall, J. S. (2006). Fungal zymosan induces leukotriene production by human mast cells through a dectin1-dependent mechanism. J. Allergy Clin. Immunol. 118, 837-843.

O'Neill, L. A. (2003). The role of MyD88-like adapters in Tolllike receptor signal transduction. Biochem. Soc. Trans. 31, 643-647.

Orinska, Z., Bulanova, E., Budagian, V., Metz, M., Maurer, M., and BulfonePaus, S. (2005). TLR3-induced activation of mast cells modulates CD8+ T-cell recruitment. Blood 106, 978-987.

Orinska, Z., Maurer, M. Mirghomizadeh, F., Bulanova E., Metz, M., Nashkevich, N., Schiemann, F., Schulmistrat, J., Budagian, V., Giron-Michel, J., Brandt, E., Paus, R., and Bulfone-Paus, S. (2007). IL-15 constrains mast celldependent antibacterial defenses by suppressing chymase activities. Nat. Med. 13, 927-934.

Ozinsky, A., Underhill, D. M., Fontenot, J. D., Hajjar, A. M., Smith, K. D., Wilson, C. B., Schroeder, L., and Aderem, A. (2000). The repertoire for pattern recognition of pathogens by the innate immune system is defined by cooperation between tolllike receptors. Proc. Natl. Acad. Sci. U.S.A. 97, 13766-13771.

Pagliari, C., Fernandes, E. R., Guedes, F., Alves, C., and Sotto, M. N. (2006). Role of mast cells as IL10 producing cells in paracoccidioidomycosis skin lesions. Mycopathologia 162, 331-335.

Patella, V., Florio, G., Petraroli, A., and Marone, G. (2000). HIV-1 gp120 induces IL-4 and IL-13 release from human Fc epsilon RI+ cells through interaction with the $\mathrm{VH} 3$ region of IgE. J. Immunol. 164, 589-595. 
Pennock, J. L., and Grencis, R. K. (2006). The mast cell and gut nematodes: damage and defence. Chem. Immunol. Allergy 90, 128-140.

Qing, C., Min, L., Rong-Cai, T., Wei-Da, L., Wu-Qing, Z., Yong-Nian, S., and Gui-Xia, L. (2011). Effect of phospholipomannan of Candida albicans on the production of interleukin 6 and interleukin 8 in monocytes. Zhongguo Yi Xue Ke Xue Yuan Xиe Bao 33, 371-374.

Rehaume, L. M., Jouault, T., and Chamaillard, M. (2010). Lessons from the inflammasome: a molecular sentry linking Candida and Crohn's disease. Trends Immunol. 31 , 171-175.

Ribbing, C., Engblom, C., Lappalainen, J., Lindstedt, K., Kovanen, P. T., Karlsson, M. A., Lundeberg, L., Johansson, C., Nilsson, G., Lunderius-Andersson, C., and Scheynius, A. (2011). Mast cells generated from patients with atopic eczema have enhanced levels of granule mediators and an impaired Dectin-1 expression. Allergy 66, 110-119.

Rogers, N. C., Slack, E. C., Edwards, A. D., Nolte, M. A., Schulz, O., Schweighoffer, E., Williams, D. L., Gordon, S., Tybulewicz, V. L., Brown, G. D., and REIS E Sousa, C. (2005). Syk-dependent cytokine induction by Dectin-1 reveals a novel pattern recognition pathway for $\mathrm{C}$ type lectins. Immunity 22, 507-517.

Romani, L., Puccetti, P., Mencacci, A., Cenci, E., Spaccapelo, R., Tonnetti, L., Grohmann, U., and Bistoni, F. (1994). Neutralization of IL-10 upregulates nitric oxide production and protects susceptible mice from challenge with Candida albicans. J. Immunol. 152, 3514-3521.

Ronnberg, E., Guss, B., and Pejler, G. (2010). Infection of mast cells with live streptococci causes a toll-like receptor 2- and cell-cell contact-dependent cytokine and chemokine response. Infect. Immun. 78, 854-864.

Saijo, S., Ikeda, S., Yamabe, K., Kakuta, S., Ishigame, H., Akitsu, A., Fujikado, N., Kusaka, T., Kubo, S., Chung, S. H., Komatsu, R., Miura, N., Adachi, Y., Ohno, N., Shibuya, K., Yamamoto, N., Kawakami, K., Yamasaki, S., Saito, T., Akira, S., and Iwakura, Y. (2010). Dectin-2 recognition of alpha-mannans and induction of Th17 cell differentiation is essential for host defense against Candida albicans. Immunity 32, 681-691.

Saijo, S., and Iwakura, Y. (2011). Dectin1 and Dectin-2 in innate immunity against fungi. Int. Immunol. 23, 467-472.

Sanchez, L. F., Hotta, H., Hotta, S., and Homma, M. (1986). Degranulation and histamine release from murine mast cells sensitized with dengue virus-immune sera. Microbiol. Immunol. 30, 753-759.

Sasaki, Y., Yoshimoto, T., Maruyama, H., Tegoshi, T., Ohta, N., Arizono, N., and Nakanishi, K. (2005). IL-18 with IL-2 protects against Strongyloides venezuelensis infection by activating mucosal mast cell-dependent type 2 innate immunity. J. Exp. Med. 202, 607-616.

Sato, K., Yang, X. L., Yudate, T., Chung, J. S., Wu, J., Luby-Phelps, K., Kimberly, R. P., Underhill, D., Cruz, P. D. Jr., and Ariizumi, K. (2006). Dectin2 is a pattern recognition receptor for fungi that couples with the Fc receptor gamma chain to induce innate immune responses. J. Biol. Chem. 281, 38854-38866.

Saunte, D. M., Tarazooie, B., Arendrup, M. C., and de Hoog, G. S. (2012). Black yeast-like fungi in skin and nail: it probably matters. Mycoses 55, 161-167.

Selander, C., Engblom, C., Nilsson, G., Scheynius, A., and Andersson, C. L. (2009). TLR2/MyD88-dependent and -independent activation of mast cell IgE responses by the skin commensal yeast Malassezia sympodialis. J. Immunol. 182, 4208-4216.

Shin, K., Watts, G. F., Oettgen, H. C., Friend, D. S., Pemberton, A. D., Gurish, M. F., and Lee, D. M. (2008). Mouse mast cell tryptase mMCP-6 is a critical link between adaptive and innate immunity in the chronic phase of Trichinella spiralis infection. J. Immunol. 180, 4885-4891.

Shirato, K., and Taguchi, F. (2009). Mast cell degranulation is induced by A549 airway epithelial cell infected with respiratory syncytial virus. Virology 386, 88-93.

Shoham, S., Huang, C., Chen, J. M., Golenbock, D. T., and Levitz, S. M. (2001). Toll-like receptor 4 mediates intracellular signaling without TNFalpha release in response to Cryptococcus neoformans polysaccharide capsule. J. Immunol. 166, 4620-4626.

Siebenhaar, F., Syska, W., Weller, K., Magerl, M., Zuberbier, T., Metz, M., and Maurer, M. (2007). Control of Pseudomonas aeruginosa skin infections in mice is mast cell-dependent. Am. J. Pathol. 170, 1910-1916.

St John, A. L., Rathore, A. P., Yap, H., Ng, M. L., Metcalfe, D. D., Vasudevan, S. G., and Abraham, S. N. (2011). Immune surveillance by mast cells during dengue infection promotes natural killer (NK) and NKT-cell recruitment and viral clearance. Proc. Natl. Acad. Sci. U.S.A. 108 9190-9195.

Steele, C., Marrero, L., Swain, S., Harmsen, A. G., Zheng, M., Brown, G. D. Gordon, S., Shellito, J. E., and Kolls, J. K. (2003). Alveolar macrophagemediated killing of Pneumocystis carinii f. sp. muris involves molecular recognition by the Dectin- 1 betaglucan receptor. J. Exp. Med. 198 1677-1688.

Sugiyama, K. (1977). Histamine release from rat mast cells induced by Sendai virus. Nature 270, 614-615.

Sundstrom, J. B., Ellis, J. E., Hair, G. A. Kirshenbaum, A. S., Metcalfe, D. D., Yi, H., Cardona, A. C., Lindsay, M. K., and Ansari, A. A. (2007). Human tissue mast cells are an inducible reservoir of persistent HIV infection. Blood 109, 5293-5300.

Supajatura, V., Ushio, H., Nakao, A., Akira, S., Okumura, K., Ra, C., and Ogawa, H. (2002). Differential responses of mast cell Toll-like receptors 2 and 4 in allergy and innate immunity. J. Clin. Invest. 109 1351-1359.

Tada, H., Nemoto, E., Shimauchi, H. Watanabe, T., Mikami, T., Matsumoto, T., Ohno, N., Tamura, H., Shibata, K., Akashi, S., Miyake, K., Sugawara, S., and Takada, H. (2002). Saccharomyces cerevisiaeand Candida albicans-derived mannan induced production of tumor necrosis factor alpha by human monocytes in a CD14- and Tolllike receptor 4-dependent manner. Microbiol. Immunol. 46, 503-512.

Tonnetti, L., Spaccapelo, R., Cenci, E. Mencacci, A., Puccetti, P., Coffman, R. L., Bistoni, F., and Romani, L. (1995). Interleukin-4 and -10 exacerbate candidiasis in mice. Eur. J. Immunol. 25, 1559-1565.

Trivedi, N. N., and Caughey, G. H. (2010). Mast cell peptidases: chameleons of innate immunity and host defense. Am. J. Respir. Cell Mol. Biol. 42, 257-267.

Urb, M., Pouliot, P., Gravelat, F. N., Olivier, M., and Sheppard, D. C. (2009). Aspergillus fumigatus induces immunoglobulin Eindependent mast cell degranulation. J. Infect. Dis. 200, 464-472.

Urban, C. F., Reichard, U., Brinkmann, V., and Zychlinsky, A. (2006). Neutrophil extracellular traps capture and kill Candida albicans yeast and hyphal forms. Cell. Microbiol. 8, 668-676.

van de Veerdonk, F. L., Netea, M. G. Jansen, T. J., Jacobs, L., Verschueren,
I., Van der Meer, J. W., and Kullberg, B. J. (2008). Redundant role of TLR9 for anti-Candida host defense. Immunobiology 213, 613-620.

Van de Voorde, J., and Leusen, I. (1983). Role of the endothelium in the vasodilator response of rat thoracic aorta to histamine. Eur. J. Pharmacol. 87, 113-120.

Varadaradjalou, S., Feger, F., Thieblemont, N., Hamouda, N. B., Pleau, J. M., Dy, M., and Arock, M. (2003). Toll-like receptor 2 (TLR2) and TLR4 differentially activate human mast cells. Eur. J. Immunol. 33, 899-906.

Vecchiarelli, A., Retini, C., Monari, C., Tascini, C., Bistoni, F., and Kozel, T. R. (1996). Purified capsular polysaccharide of Cryptococcus neoformans induces interleukin-10 secretion by human monocytes. Infect. Immun. 64, 2846-2849.

Villamon, E., Gozalbo, D., Roig, P., Murciano, C., O'Connor, J. E., Fradelizi, D., and Gil, M. L. (2004a). Myeloid differentiation factor 88 (MyD88) is required for murine resistance to Candida albicans and is critically involved in Candida -induced production of cytokines. Eur. Cytokine Netw. 15, 263-271.

Villamon, E., Gozalbo, D., Roig, P., O'Connor, J. E., Ferrandiz, M. L., Fradelizi, D., and Gil, M. L. (2004b). Toll-like receptor 2 is dispensable for acquired host immune resistance to Candida albicans in a murine model of disseminated candidiasis. Microbes Infect. 6, 542-548.

Villamon, E., Roig, P., Gil, M. L., and Gozalbo, D. (2005). Toll-like receptor 2 mediates prostaglandin $E(2)$ production in murine peritoneal macrophages and splenocytes in response to Candida albicans. Res. Microbiol. 156, 115-118.

von Kockritz-Blickwede, M., Goldmann, O., Thulin, P., Heinemann, K., Norrby-Teglund, A., Rohde, M., and Medina, E. (2008). Phagocytosisindependent antimicrobial activity of mast cells by means of extracellular trap formation. Blood 111, 3070-3080

Wang, J. E., Warris, A., Ellingsen, E. A., Jorgensen, P. F., Flo, T. H., Espevik, T., Solberg, R., Verweij, P. E., and Aasen, A. O. (2001). Involvement of CD14 and toll-like receptors in activation of human monocytes by Aspergillus fumigatus hyphae. Infect. Immun. 69, 2402-2406

Wang, Z., Lai, Y., Bernard, J. J., Macleod, D. T., Cogen, A. L., Moss, B., and di Nardo, A. (2012). Skin mast cells protect mice against vaccinia virus by triggering mast cell receptor 
S1PR2 and releasing antimicrobial peptides. J. Immunol. 188, 345-357.

Warris, A., Netea, M. G., Verweij, P. E., Gaustad, P., Kullberg, B. J., Weemaes, C. M., and Abrahamsen, T. G. (2005). Cytokine responses and regulation of interferon-gamma release by human mononuclear cells to Aspergillus fumigatus and other filamentous fungi. Med. Mycol. 43, 613-621.

Wedde-Beer, K., Hu, C., Rodriguez, M. M., and Piedimonte, G. (2002). Leukotrienes mediate neurogenic inflammation in lungs of young rats infected with respiratory syncytial virus. Am. J. Physiol. Lung Cell Mol. Physiol. 282, L1143-L1150.

Wedemeyer, J., Tsai, M., and Galli, S. J. (2000). Roles of mast cells and basophils in innate and acquired immunity. Curr. Opin. Immunol. 12, 624-631.

Weis, W. I., Taylor, M. E., and Drickamer, K. (1998). The Ctype lectin superfamily in the immune system. Immunol. Rev. 163, 19-34.

Willment, J. A., and Brown, G. D. (2008). C-type lectin receptors in antifungal immunity. Trends Microbiol. 16, 27-32.
Xu, X., Zhang, D., Lyubynska, N., Wolters, P. J., Killeen, N. P., Baluk, P., McDonald, D. M., Hawgood, S., and Caughey, G. H. (2006). Mast cells protect mice from Mycoplasma pneumonia. Am. J. Respir. Crit. Care Med. 173, 219-225.

Yadav, M., and Schorey, J. S. (2006). The beta-glucan receptor dectin-1 functions together with TLR2 to mediate macrophage activation by mycobacteria. Blood 108, 3168-3175.

Yamaguchi, N., Sugita, R., Miki, A., Takemura, N., Kawabata, J., Watanabe, J., and Sonoyama, K. (2006). Gastrointestinal Candida colonisation promotes sensitisation against food antigens by affecting the mucosal barrier in mice. Gut 55, 954-960.

Yamaki, K., and Yoshino, S. (2011). Aspergillus oryzae lectin induces anaphylactoid oedema and mast cell activation through its interaction with fucose of mast cell-bound nonspecific IgE. Scand. J. Immunol. 74, 445-453.

Yamamoto, M., Sato, S., Hemmi, H., Hoshino, K., Kaisho, T., Sanjo, H., Takeuchi, O., Sugiyama, M., Okabe, M., Takeda, K., and Akira, S.
(2003). Role of adaptor TRIF in the MyD88-independent toll-like receptor signaling pathway. Science 301, 640-643.

Yanez, A., Flores, A., Murciano, C., O'Connor, J. E., Gozalbo, D., and Gil, M. L. (2010). Signalling through TLR2/MyD88 induces differentiation of murine bone marrow stem and progenitor cells to functional phagocytes in response to Candida albicans. Cell. Microbiol. 12, 114-128.

Yang, Z., and Marshall, J. S. (2009) Zymosan treatment of mouse mast cells enhances dectin-1 expression and induces dectin-1-dependent reactive oxygen species (ROS) generation. Immunobiology 214 321-330.

Zhu, F. G., and Marshall, J. S. (2001). CpG-containing oligodeoxynucleotides induce TNF-alpha and IL-6 production but not degranulation from murine bone marrow-derived mast cells. J. Leukoc. Biol. 69 , 253-262.

Zwolinska-Wcislo, M., Brzozowski, T., Budak, A., Kwiecien, S., Sliwowski, Z., Drozdowicz, D., Trojanowska, D., Rudnicka-Sosin, L., Mach, T., Konturek, S. J., and Pawlik, W.
W. (2009). Effect of Candida colonization on human ulcerative colitis and the healing of inflammatory changes of the colon in the experimental model of colitis ulcerosa. J. Physiol. Pharmacol. 60, 107-118.

Conflict of Interest Statement: The authors declare that the research was conducted in the absence of any commercial or financial relationships that could be construed as a potential conflict of interest.

Received: 03 April 2012; accepted: 19 May 2012; published online: 13 June 2012.

Citation: Saluja R, Metz M and Maurer $M$ (2012) Role and relevance of mast cells in fungal infections. Front. Immun. 3:146. doi: 10.3389/fimmu.2012.00146 This article was submitted to Frontiers in Inflammation, a specialty of Frontiers in Immunology.

Copyright (c) 2012 Saluja, Metz and Maurer. This is an open-access article distributed under the terms of the Creative Commons Attribution Non Commercial License, which permits noncommercial use, distribution, and reproduction in other forums, provided the original authors and source are credited. 